\title{
PRELIMINARY TEST OF MINING WASTEWATER CONTAINING IRON (III) AND ALUMINIUM (III) ON Scirpus grossus IN PHYTOREMEDIATION PROCESS
}

\author{
Nur 'Izzati Ismail "a , Siti Rozaimah Sheikh Abdullah ${ }^{1, b}$, Mushrifah Idris ${ }^{2, \mathrm{c}}$, \\ Hassimi Abu Hasan ${ }^{1, d}$, Nadya Hussin AL Sbani ${ }^{1, e}$ and Omar Hamed Jehawi ${ }^{1, f}$ \\ ${ }^{1}$ Department of Chemical Engineering and Process, Faculty of Engineering and Built Environment, \\ National University of Malaysia, 43600 Bangi, Selangor Darul Ehsan, Malaysia \\ ${ }^{2}$ Tasik Chini Research Center, Faculty of Science and Technology, National University of Malaysia, \\ 43600 Bangi, Selangor Darul Ehsan, Malaysia \\ aezaty_ismail@yahoo.com, ${ }^{b}$ rozaimah@ukm.edu.my, 'cmushrifahidris@gmail.com, \\ dsimiabuhasan@gmail.com, 'eneam2009@yahoo.com, 'omerjehawi@yahoo.com
}

Keywords: Preliminary test; mining wastewater; phytoremediation; Scirpus grossus

\begin{abstract}
Preliminary test was conducted to physically observe and determine the range of $\mathrm{Fe}$ and Al concentrations that Scirpus grossus can grow and survive. Pails of $3 \mathrm{~L}$ containing $3 \mathrm{~kg}$ of sand and 42 days old $S$. grossus were exposed to different concentrations of Fe and Al solution mixture for 21 days. The mass ratio between $\mathrm{Fe}$ and $\mathrm{Al}$ in the solution mixture was 3:1. After 21 days of exposure, the plants had shown that they could grow and survive in concentrations up to $300 \mathrm{mg} / \mathrm{L}$ $\mathrm{Fe}+100 \mathrm{mg} / \mathrm{L} \mathrm{Al}$. Effect concentration $\left(\mathrm{EC}_{50}\right)$ value for single $\mathrm{Fe}$ and $\mathrm{Al}$ toxicity to $\mathrm{S}$. grossus was predicted between $300 \mathrm{mg} / \mathrm{L} \mathrm{Fe}+100 \mathrm{mg} / \mathrm{L} \mathrm{Al}$ and $450 \mathrm{mg} / \mathrm{L} \mathrm{Fe}+150 \mathrm{mg} / \mathrm{L} \mathrm{Al}$. Therefore, it is suggested for the next study of phytotoxicity the Fe and Al concentrations range may start as low as $30 \mathrm{mg} / \mathrm{L} \mathrm{Fe}+10 \mathrm{mg} / \mathrm{L} \mathrm{Al} \mathrm{up} \mathrm{to} 450 \mathrm{mg} / \mathrm{L} \mathrm{Fe}+150 \mathrm{mg} / \mathrm{L} \mathrm{Al}$.
\end{abstract}

\section{Introduction}

Heavy metals may enter the environment through several points of sources either naturally through weathering, erosion of parent rocks, atmospheric deposition and volcanic activities or anthropogenic activities such as mining, smelting, electroplating, sewage irrigation, addition of manures, widely use of fertilizers and pesticides [1,2]. Heavy metals are natural constituents of the Earth's crust and they are stable and cannot be degraded or destroyed [3]. They tend to accumulate in soils, water and sediments [4]. Among those, mining is responsible for heavy metal contamination [5].

In this study, an active mining area near Tasik Chini, Pahang was selected as a study area. The mineral being removed is bauxite. Bauxite mining can lead to iron and aluminium contamination to the environment since the ores are mainly composed of $\mathrm{Al}_{2} \mathrm{O}_{3}, \mathrm{SiO}_{2}, \mathrm{Fe}_{2} \mathrm{O}_{3}$ and $\mathrm{TiO}_{2}$ [6] at which the mass ratio between these compounds are different in every country and also different in different region in a country [7]. It can happen naturally (i.e. rain) and also due to human (i.e. mining activity). The conversion of iron to ferric hydroxide precipitate can generate toxic derivatives and this will lead to infection, neoplasia, cardiomyopathy, arthropathy, and various endocrine and neurode- generative disorders in human [8]. Likewise, aluminium also has the toxic influences which will lead to Parkinson's dementia, amyotrophic lateral sclerosis and Alzheimer's disease [9].

Due to the toxicity effects of the metals, many treatments being applied to reduce the concentrations of heavy metals below the allowable limits. Conventional treatment methods on heavy metals involved for water are reverse-osmosis, ion exchange, electrodialysis, adsorption by activated carbon, chemical precipitation, disinfection and nanofiltration $[10,11,12]$. However, those 
treatments are generally costly, labour-intensive, can generate secondary waste or sludge, energy intensive and metal specific $[4,12]$. Therefore, a cost effective and environmental friendly approach $[13,14]$ method like phytoremediation should be featured. Phytoremediation is a remediation method at which plant plays an important role to extract, degrade, contain or immobilize pollutants in soil, groundwater, surface water and other contaminated media [15]. It involves several mechanisms which are rhizofiltration, phytostabilization, phytotransformation, phytoextraction and phytovolatilization. In this study, a native plant of Scirpus grossus in Tasik Chini, Pahang was used. It has the ability to remediate iron and aluminium from contaminated areas since it was found in bauxite mining areas in Sungai Jemberau, Tasik Chini, Pahang [16]. It is a perennial tropical aquatic plant with common names of giant bulrush, greater club-rush, rumput menderong (Malaysia), mensiang and walingi (Indonesia) [17]. The objective of this test was to estimate the maximum concentration of the mixture of Fe (III) and Al (III) that the S. grossus has the ability to survive and tolerate. The results from this study can be used in future phytotoxicity study.

\section{Materials and Methods}

Propagation of $\boldsymbol{S}$. grossus and preparation of synthetic mining wastewater. $S$. grossus was planted in garden soil which contain top soil, organic fertilizer i.e. cow manure and sand with ratio of $3: 2: 1$. About 18 healthy plants of $S$. grossus with 42 days old were exposed to various mixture concentrations of $\mathrm{Fe}$ and $\mathrm{Al}$. Before the preliminary test was conducted, the analysis of soil mining collected from Tasik Chini was done in order to determine the mass ratio between iron and aluminium. From the analysis, it was found that the mass ratio of $\mathrm{Fe}$ and $\mathrm{Al}$ was 3:1 [16]. The result from this analysis was used during the preliminary test of $S$. grossus. Stock solutions of $\mathrm{Fe}$ and $\mathrm{Al}$ were prepared separately by dissolving iron (III) chloride hexahydrate $\left(\mathrm{FeCl}_{3} \cdot 6 \mathrm{H}_{2} \mathrm{O}\right)$ (Friendemann Schmidt, U.K) and aluminium sulphate $\left(\mathrm{Al}_{2}\left(\mathrm{SO}_{4}\right)_{3} \cdot 16 \mathrm{H}_{2} \mathrm{O}\right)(\mathrm{R} \& \mathrm{M}$ Marketing,U.K) in distilled water. The dilutions for both stock solutions were done according to the required mixture concentration as in Table 1.

Table 1 Concentration of heavy metals in a pail and its function

\begin{tabular}{|c|c|c|c|c|c|c|}
\hline Pail no. & Pail 1 & Pail 2 & Pail 3 & Pail 4 & Pail 5 & Pail 6 \\
\hline \multicolumn{7}{|c|}{ Concentration of heavy metals in a pail } \\
\hline$[\mathrm{mg} / \mathrm{L} \mathrm{Fe}]$ & 0 & 150 & 300 & 450 & 600 & 750 \\
\hline$[\mathrm{mg} / \mathrm{L} \mathrm{Al}]$ & 0 & 50 & 100 & 150 & 200 & 250 \\
\hline Function & $\mathrm{PC}$ & $\mathrm{C} 1$ & $\mathrm{C} 2$ & $\mathrm{C} 3$ & $\mathrm{C} 4$ & $\mathrm{C} 5$ \\
\hline
\end{tabular}

$\mathrm{PC}=$ Plant control

$\mathrm{C} 1-\mathrm{C} 5=$ Contaminant $1-$ Contaminant 5

Preparation of experimental setup. $3 \mathrm{~kg}$ of sand was filled in $3 \mathrm{~L}$ pail which was used as the batch reactor. Subsurface flow system was used since it was proven that it was more efficient than free surface flow system [18]. The duration of this test was 21 days. The physical observations of plants were observed on Day 0 and Day 21. At the end of the observation day, the percentage of cumulative effect was calculated using Eq. 1.

$$
\text { Cumulative effect, } \%=\frac{\text { number of died plant }}{\text { number of total plant }} \times 100
$$

Quantitative description on plant growth. The plant growth of $S$. grossus was physically observed throughout the sampling period either healthy (overall leaves were green), withered (some leaves changing color to yellow) or died (the whole leaves were brown and dried). 


\section{Results and Discussion}

Table 2 summarizes the physical observation of S. grossus on Day 0 and Day 21. Based on the plant growth observation, $S$. grossus remained healthy until the end of experimental period for PC. But, all three plants were dead for $\mathrm{C} 3, \mathrm{C} 4$ and $\mathrm{C} 5$. For $\mathrm{C} 1$ and $\mathrm{C} 2$, only one plant was died. The number of plants died increased as the concentrations of the Fe and $\mathrm{Al}$ increased. The dead of $S$. grossus was due to the Fe and $\mathrm{Al}$ toxicity which was also reported by many researchers due to the growth inhibition either in the roots or towards the upper part of the plants [19,20,21]. Fig. 1 depicts the effect concentration $\left(\mathrm{EC}_{50}\right)$ value for single $\mathrm{Fe}$ and $\mathrm{Al}$ toxicity to $S$. grossus which was predicted between $300 \mathrm{mg} / \mathrm{L} \mathrm{Fe}$ and $100 \mathrm{mg} / \mathrm{L} \mathrm{Al}$ to $450 \mathrm{mg} / \mathrm{L} \mathrm{Fe}$ and $150 \mathrm{mg} / \mathrm{L} \mathrm{Al}$.

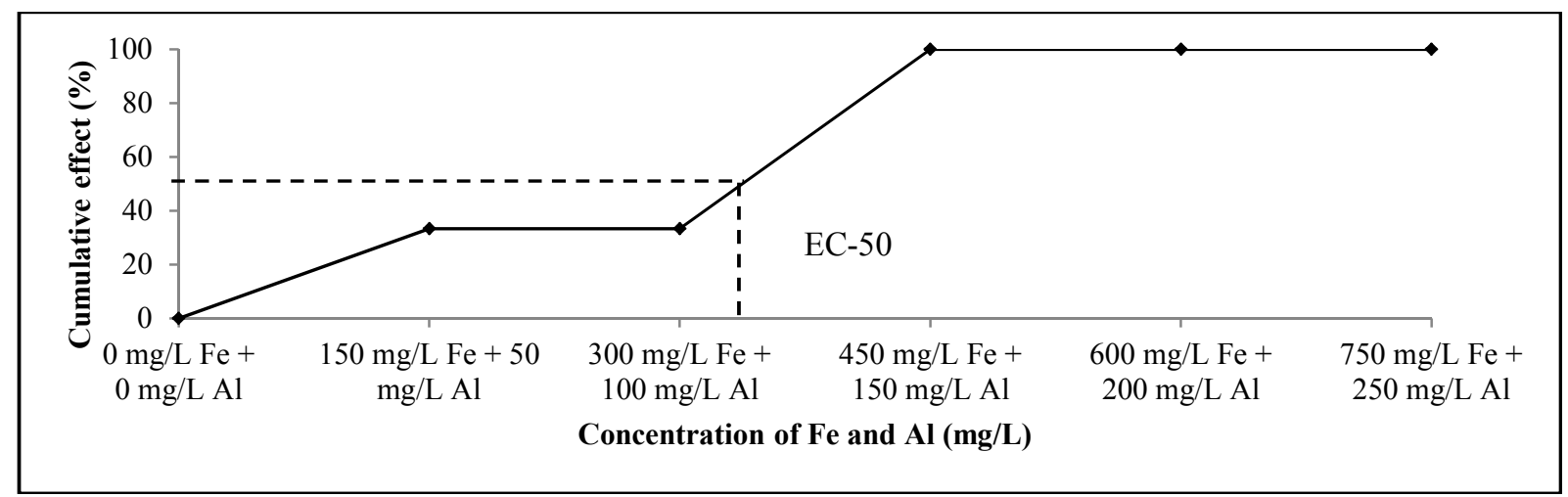

Fig. $1 \mathrm{Fe}$ and $\mathrm{Al}$ toxicity to S. grossus at the end of exposure period

Based on the observations, the higher the concentration of $\mathrm{Fe}$ and $\mathrm{Al}$, the greater the effect percentage and the faster died conditions occurred. Therefore, it is suggested for the future study of phytotoxicity can use $\mathrm{Fe}$ and $\mathrm{Al}$ concentrations range as low as $30 \mathrm{mg} / \mathrm{L} \mathrm{Fe}+10 \mathrm{mg} / \mathrm{L} \mathrm{Al}$ up to 450 $\mathrm{mg} / \mathrm{L} \mathrm{Fe}+150 \mathrm{mg} / \mathrm{L} \mathrm{Al}$.

\section{Summary}

The results showed that as the concentrations of the mixture of $\mathrm{Fe}$ and $\mathrm{Al}$ increased the withering symptoms and plant death also increased in parallel reducing the survival of S. grossus. After 21 days of exposure, the plants had shown that they could grow and survive in concentrations up to $300 \mathrm{mg} / \mathrm{L} \mathrm{Fe}+100 \mathrm{mg} / \mathrm{L} \mathrm{Al}$ with survival percentage of $66.7 . \mathrm{EC}_{50}$ value for single $\mathrm{Fe}$ and $\mathrm{Al}$ toxicity to $S$. grossus which was predicted between $300 \mathrm{mg} / \mathrm{L} \mathrm{Fe}+100 \mathrm{mg} / \mathrm{L} \mathrm{Al}$ to $450 \mathrm{mg} / \mathrm{L} \mathrm{Fe}$ and $150 \mathrm{mg} / \mathrm{L} \mathrm{Al}$. Therefore, the future phytotoxicity study can start from $30 \mathrm{mg} / \mathrm{L} \mathrm{Fe}+10 \mathrm{mg} / \mathrm{L} \mathrm{Al}$ until $450 \mathrm{mg} / \mathrm{L} \mathrm{Fe}+150 \mathrm{mg} / \mathrm{L} \mathrm{Al}$.

\section{Acknowledgement}

The authors would like to thank Tasik Chini Research Centre, Universiti Kebangsaan Malaysia (UKM) and Ministry of Higher Education, Malaysia for granting this project through LRGS/BU/2012/UKM/BS. 
Table 2 Plant physical observation during preliminary test for $S$. grossus

\begin{tabular}{ccccccc}
\hline & \multicolumn{5}{c}{ Heavy metals concentration } \\
\cline { 2 - 7 } $\begin{array}{c}\text { Time of } \\
\text { exposure } \\
\text { (Day) }\end{array}$ & $\begin{array}{c}0[\mathrm{mg} / \mathrm{L} \mathrm{Fe}] \\
+0[\mathrm{mg} / \mathrm{L} \mathrm{Al}]\end{array}$ & $\begin{array}{c}150[\mathrm{mg} / \mathrm{L} \mathrm{Fe}] \\
+50[\mathrm{mg} / \mathrm{L} \mathrm{Al}]\end{array}$ & $\begin{array}{c}300[\mathrm{mg} / \mathrm{L} \mathrm{Fe}] \\
+100[\mathrm{mg} / \mathrm{L} \mathrm{Al}]\end{array}$ & $\begin{array}{c}450[\mathrm{mg} / \mathrm{L} \mathrm{Fe}] \\
+150[\mathrm{mg} / \mathrm{L} \mathrm{Al}]\end{array}$ & $\begin{array}{c}600[\mathrm{mg} / \mathrm{L} \mathrm{Fe}] \\
+200[\mathrm{mg} / \mathrm{L} \mathrm{Al}]\end{array}$ & $\begin{array}{c}750[\mathrm{mg} / \mathrm{L} \mathrm{Fe}] \\
+250[\mathrm{mg} / \mathrm{L} \mathrm{Al}]\end{array}$ \\
\cline { 2 - 7 } & $\mathrm{PC}$ & $\mathrm{C} 1$ & $\mathrm{C} 2$ & $\mathrm{C} 3$ & $\mathrm{C} 4$ & $\mathrm{C} 5$ \\
\hline
\end{tabular}

00

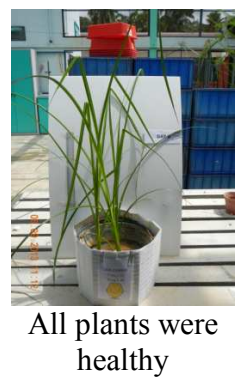

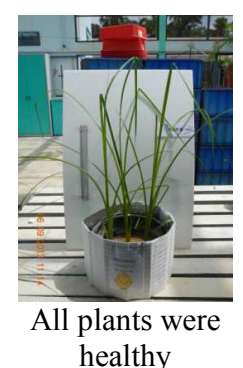

healthy
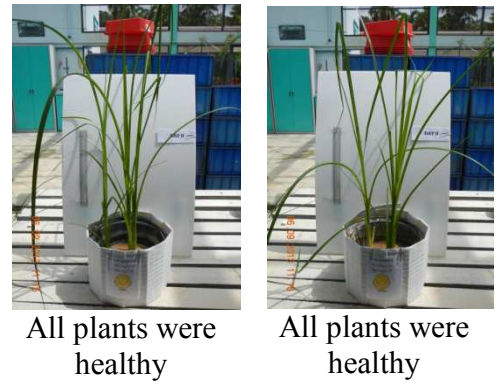
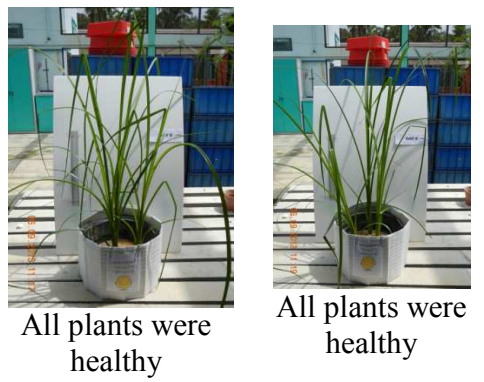

21

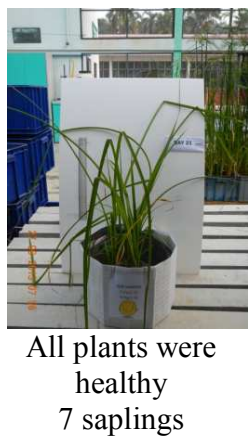

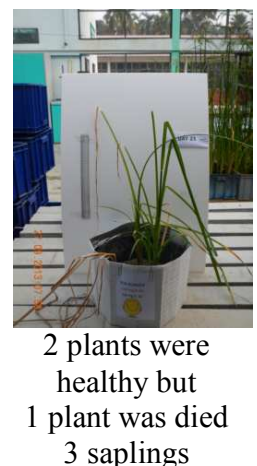

3 saplings

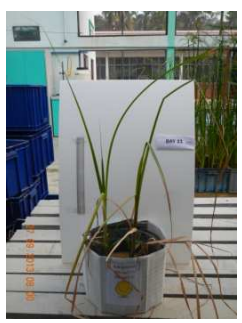

2 plants were healthy but yellowish at the end of the leaves 1 plant was died 4 saplings
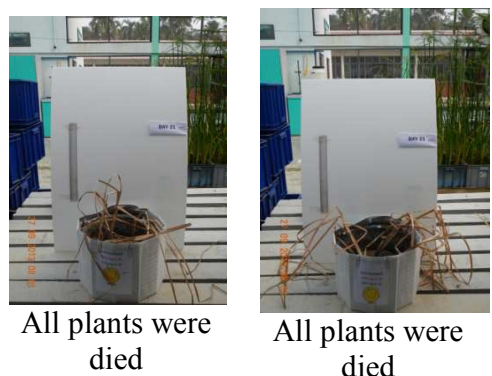

All plants were died

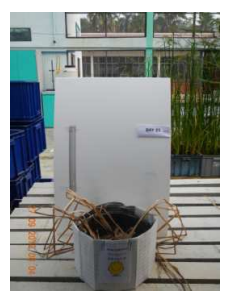

All plants were died

\section{References}

[1] A. Babu, J. Kim, B. Oh, Enhancement of heavy metal phytoremediation by Alnus firma with endophytic Bacillus thuringiensis GDB-1, Journal of Hazardous Materials. 250- 251 (2013) $477-483$.

[2] Y. Ma, M. Rajkumar, Y. Luo, H. Freitas, Phytoextraction of heavy metal polluted soils using Sedum plumbizincicola inoculated with metal mobilizing Phyllobacterium myrsinacearum RC6b, Chemosphere, Article in Press. (2013).

[3] C.D. Jadia, M.H. Fulekar, Phytoremediation: The application of vermicompost to remove zinc, cadmium, copper, nickel and lead by sunflower plant, Environmental Engineering and Management Journal. 7(5) (2008) 547-558.

[4] L. Vardanyan, K. Schmieder, H. Sayadyan, T. Heege, J. Heblinski, T. Agyemang, J. De, J. Breuer, Heavy metal accumulation by certain aquatic macrophytes from Lake Sevan (Armenia), The $12^{\text {th }}$ World Lake Conference. (2008) 1028-1038.

[5] V. Sheoran, A.S. Sheoran, P. Poonia, Role of hyperaccumulators in phytoextraction of metals from contaminated mining sites: A review, Environmental Science and Technology. 41 (2011) 168-214. 
[6] J. Gu, Z.L. Huang, H.P. Fan, Z.G. Jin, Z.F. Yan, J.W. Zhang, Mineralogy, geochemistry, and genesis of lateritic bauxite deposits in the Wuchuan-Zheng'an-Daozhen area, Northern Guizhou Province, China, Journal of Geochemical Exploration. 130 (2013) 44-59.

[7] W.C. Liu, J.K. Yang, B. Xiao, Review on treatment and utilization of bauxite residues in China, International Journal of Mineral Processing. 93 (2009) 220-231.

[8] S. Bordoloi, S.K. Nath, R.K. Dutta, Iron ion removal from groundwater using banana ash, carbonates and bicarbonates of $\mathrm{Na}$ and K, and their mixtures, Desalination. 281 (2011) 190198.

[9] M.A. Dzulfakar, M.S. Shaharuddin, A.A. Muhaimi, A.I. Syazwan, Risk Assessment of aluminum in drinking water between two residential areas, Water. 3 (2011) 882-893.

[10] A.P.G.C. Marques, A.O.S.S. Rangel, P.M.L. Castro, Remediation of heavy metal contaminated soils: Phytoremediation as a potentially promising clean-up technology, Critical Reviews in Environmental Science and Technology. 39 (2009) 622-654.

[11] H. Mokhtar, N. Morad, F.F.A. Fizri, Hyperaccumulation of copper by two species of aquatic plants, 2011 International Conference on Environmental Science and Engineering. IPCBEE vol. 8 (2011) 115-118.

[12] S.K. Prajapati, N. Meravi, S. Singh, Phytoremediation of chromium and cobalt using Pistia stratiotes: A sustainable approach, International Academy of Ecology and Environmental Sciences. 2(2) (2012) 136-138.

[13] Z. Deng, R. Zhang, Y. Shi, L. Hu, H. Tan, L. Cao, Enhancement of phytoremediation of Cdand $\mathrm{Pb}$-contaminated soils by self-fusion of protoplasts from endophytic fungus Mucor sp. CBRF59, Chemosphere. 91 (2013) 41-47.

[14] R. Yang, C. Luo, Y. Chen, G. Wang, Y. Xu, Z. Shen, Copper-resistant bacteria enhance plant growth and copper phytoextraction, International Journal of Phytoremediation. 15 (2013) 573-584.

[15] Environmental Protection Agency. 2010. Phytotechnologies for Site Cleanup. EPA 542-F-10009. October 2013. Information on http://www.cluin.org/download/remed/phytotrchnologiesfactsheet.pdf

[16] N.I. Ismail, S.R.S. Abdullah, M. Idris, Assessment of heavy metals in water, sediment and plants in Tasik Chini, $2^{\text {nd }}$ International Conference of Chemical Engineering and Industrial Biotechnology 2013 (ICCEIB 2013). 28 - 29 August 2013, Pahang, Malaysia.

[17] B.V. Tangahu, S.R.S. Abdullah, H. Basri, M. Idris, N. Anuar, M. Mukhlisin, Phytotoxicity of wastewater containing lead $(\mathrm{Pb})$ effects Scirpus grossus, International Journal of Phytoremediation. 15 (2013) 814-826.

[18] I.A. Albaldawi, S.R.S. Abdullah, F. Suja, N. Anuar, M. Idris, Comparative performance of free surface and sub-surface flow systems in the phytoremediation of hydrocarbons using Scirpus grossus, Journal ofEnvironmental Management. 130 (2013) 324-330.

[19] W. Xing, D.H. Li, G.H. Liu, Antioxidative responses of Elodea nuttallii (Planch.) H. St. John to short-term iron exposure, Plant Physiology and Biochemistry. 48 (2010) 873-878.

[20] J. Kovacik, B. Klejdus, J. Hedbavny, Effect of aluminium uptake on physiology, phenols and amino acids in Matricaria chamomilla plants, Journal of Hazardous Materials. 178 (2010) 949-955.

[21] A.I. Siqueira-Silva, L.C. Silva, A.A. Azevedo, M.A. Oliva, Iron plaque formation and morphoanatomy of roots from species of restinga subjected to excess iron, Ecotoxicology and Environmental Safety. 78 (2012) 265-275. 